\title{
COMENTÁRIOS SOBRE MINHA TRADUÇÃO SUECA DO CONTO “O CÔNEGO OU METAFÍSICA DO ESTILO”, DE MACHADO DE ASSIS
}

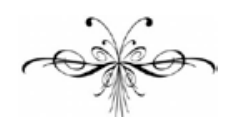

MACHAdO DE Assis

HANS BERGGREN

\section{O CÔNEGO OU METAFÍSICA DO ESTILO}

- "Vem do Líbano, esposa minha, vem do Líbano, vem... As mandrágoras deram o seu cheiro. Temos às nossas portas toda a casta de pombos...”

— "Eu vos conjuro, filhas de Jerusalém, que se encontrardes o meu amado, lhe façais saber que estou enferma de amor..."

Era assim, com essa melodia do velho drama de Judá, que procuravam um ao outro na cabeça do Cônego Matias um substantivo e um adjetivo... Não me interrompas, leitor precipitado; sei que não acreditas em nada do que vou dizer. Di-lo-ei, contudo, a despeito da tua pouca fé, porque o dia da conversão pública há de chegar.

Nesse dia, - cuido que por volta de 2222, — o paradoxo despirá as asas para vestir a japona de uma verdade comum. Então esta página merecerá, mais que favor, apoteose. Hão de

\section{KANIKEN, ELLER STILENS METAFYSIK}

"Kom med mig från Libanon, min brud, kom med mig från Libanon ... Kärleksäpplena utsända redan sin doft, och vid våra dörrar finnas alla slags kostbara frukter ...”

"Jag besvär eder, I Jerusalems döttrar, om I finnen min vän så sägen ja, vad skolen I säga honom? Att jag är sjuk av kärlek!”

Det var på det sättet, till denna melodi från det gamla dramat om Judéen, som ett substantiv och ett adjektiv sökte varandra i kaniken Matias huvud ... Avbryt mig inte, överilade läsare; jag vet att du inte tror på någonting av vad jag tänker säga. Ändå skall jag säga det, trots din klentro, ty den allmänna omvändelsens dag skall en gång komma.

Den dagen - jag tror det blir runt år 2222 - skall paradoxen ta av sig vingarna för att ikläda sig en vanlig sannings enkla jacka. Då kommer dessa rader att förtjäna mer än lovord, 
traduzi-la em todas as línguas. As academias e institutos farão dela um pequeno livro, para uso dos séculos, papel de bronze, corte-dourado, letras de opala embutidas, e capa de prata fosca. Os governos decretarão que ela seja ensinada nos ginásios e liceus. As filosofias queimarão todas as doutrinas anteriores, ainda as mais definitivas, e abraçarão esta psicologia nova, única verdadeira, e tudo estará acabado. Até lá passarei por tonto, como se vai ver.

Matias, cônego honorário e pregador efetivo, estava compondo um sermão quando começou o idílio psíquico. Tem quarenta anos de idade, e vive entre livros e livros para os lados da Gamboa. Vieram encomendar-lhe o sermão para certa festa próxima; ele que se regalava então com uma grande obra espiritual, chegada no último paquete, recusou o encargo; mas instaram tanto, que aceitou.

- Vossa Reverendíssima faz isto brincando, disse o principal dos festeiros.

Matias sorriu manso e discreto, como devem sorrir os eclesiásticos e os diplomatas. Os festeiros despediram-se com grandes gestos de veneração, e foram anunciar a festa nos jornais, com a declaração de que pregava ao Evangelho o Cônego Matias "um dos ornamentos do clero brasileiro". Este “ornamento do clero" tirou ao cônego a vontade de almoçar, quando ele o leu agora de manhã; e só por estar ajustado, é que se meteu a escrever o sermão.

Começou de má vontade, mas no fim de alguns minutos já trabalhava com amor. A inspiração, com os olhos no céu, e a meditação, com os olhos no chão, ficam a um e outro lado do ja, apoteos. De kommer att översättas till alla språk. Akademierna och instituten kommer att göra en liten bok av dem att brukas under sekler, med papper av brons, guldsnitt, bokstäver av inlagd opal och band i mattpolerat silver. Regeringarna kommer att påbjuda att de skall läras ut i gymnasier och läroverk. Filosofierna kommer att bränna alla tidigare doktriner, även de mest slutgiltiga, och omfamna denna nya och enda sanna psykologi, och allt kommer att vara fullbordat. Fram till dess kommer jag att betraktas som galen, skall det visa sig.

Matias, honorärkanik och effektiv predikant, skrev på en predikan när den psykiska romansen började. Han var fyrtio år gammal och levde bland böcker och ännu fler böcker utåt Gamboa till. De hade kommit och beställt en predikan till en förestående fest; han som just njöt av ett stort andligt verk som anlänt med senaste postbåten tackade nej till uppdraget, men de var så enträgna att han till slut accepterade.

"Det här gör ers högvördighet lekande lätt", sade festkommitténs ordförande.

Matias log milt och diskret så som kyrkans män och diplomaterna bör le. Festarrangörerna tog farväl med stora vördnadsbetygelser och annonserade festen i tidningarna med tillkännagivandet att evangelium skulle predikas av kaniken Matias, "en av det brasilianska prästerskapets prydnader”. Utnämningen till "en prästerskapets prydnad", fick kaniken att tappa matlusten när han läste det nu i morse, och endast därför att det var avtalat satte han sig att skriva predikotexten.

Han började utan större lust, men efter några minuter arbetade han redan med kärlek. På var sin sida av stolsryggen sitter inspirationen, med blicken mot himlen, och meditationen, 
espaldar da cadeira, dizendo ao ouvido do cônego mil coisas místicas e graves. Matias vai escrevendo, ora devagar, ora depressa. As tiras saem-lhe das mãos, animadas e polidas. Algumas trazem poucas emendas ou nenhumas. De repente, indo escrever um adjetivo, suspende-se; escreve outro e risca-o; mais outro, que não tem melhor fortuna. Aqui é o centro do idílio. Subamos à cabeça do cônego.

Upa! Cá estamos. Custou-te, não, leitor amigo? É para que não acredites nas pessoas que vão ao Corcovado, e dizem que ali a impressão da altura é tal, que o homem fica sendo coisa nenhuma. Opinião pânica e falsa, falsa como Judas e outros diamantes. Não creias tu nisso, leitor amado. Nem Corcovados, nem Himalaias valem muita coisa ao pé da tua cabeça, que os mede. Cá estamos. Olha bem que é a cabeça do cônego. Temos à escolha um ou outro dos hemisférios cerebrais; mas vamos por este, que é onde nascem os substantivos. Os adjetivos nascem no da esquerda. Descoberta minha, que, ainda assim, não é a principal, mas a base dela, como se vai ver. Sim, meu senhor, os adjetivos nascem de um lado, e os substantivos de outro, e toda a sorte de vocábulos está assim dividida por motivo da diferença sexual...

\section{- Sexual?}

Sim, minha senhora, sexual. As palavras têm sexo. Estou acabando a minha grande memória psico-léxicológica, em que exponho e demonstro esta descoberta. Palavra tem sexo. outras?

— Mas, então, amam-se umas às

Amam-se umas às outras. E casam-se. O casamento delas é o que chamamos estilo. Senhora minha, confesse que não entendeu nada. med blicken mot marken, och viskar tusen gåtfulla och allvarliga ting i kanikens öra. Matias skriver, än långsamt, än snabbt. Fraserna flyter livliga och polerade ur hans penna. Några rader får ändringar, men de är få. Han ska just skriva ett adjektiv när han hejdar sig; skriver ett annat och stryker över det; och så ännu ett som inte har större tur. Här är romansens centrum. Låt oss klättra upp i kanikens huvud.

Åhej! Här är vi. Det var väl inte så besvärligt, min läsande vän? Det här är för att du inte ska tro på människor som åker upp till Corcovado och säger att däruppe är känslan av höjden så enorm att människan krymper till ingenting. En panisk och felaktig uppfattning, falsk som Judas och andra sköna juveler. Det ska du inte tro på, kära läsare. Varken Corcovado eller Himalaya är mycket värt jämfört med ditt huvud som mäter dem. Här är vi. Betrakta hur kanikens huvud är inrättat. Vi har två hjärnhalvor att välja mellan, men vi tar den här, där substantiven föds. Adjektiven föds i den vänstra. Det är en upptäckt jag har gjort, visserligen inte den främsta, men grunden för denna, vilket kommer att visa sig. Ja, min herre, adjektiven föds på den ena sidan och substantiven på den andra och alla slags ord är på det viset uppdelade efter sexuella skillnader ...

- Sexuella?

Ja, min fru, sexuella. Orden har kön. Jag är i färd med att avsluta mitt stora psyko-lexiko-logiska memoarverk, vari jag framlägger och demonstrerar denna upptäckt. Ord har kön. varandra?

- Men i så fall, älskar de

De älskar varandra. Och de gifter sig. Deras giftermål är vad vi kallar stil. Min fru, medge att ni inte har förstått ett dugg. 
— Confesso que não.

Pois entre aqui também na cabeça do cônego. Estão justamente a suspirar deste lado. Sabe quem é que suspira? é o substantivo de há pouco, o tal que o cônego escreveu no papel, quando suspendeu a pena. Chama por certo adjetivo, que lhe não aparece: "Vem do Líbano, vem...” E fala assim, pois está em cabeça de padre; se fosse de qualquer pessoa do século, a linguagem seria a de Romeu: "Julieta é o sol... ergue-te, lindo sol.” Mas em cérebro eclesiástico, a linguagem é a das Escrituras. Ao cabo, que importam fórmulas? Namorados de Verona ou de Judá falam todos o mesmo idioma, como acontece com o thaler ou o dólar, o florim ou a libra, que é tudo o mesmo dinheiro.

Portanto, vamos lá por essas circunvoluções do cérebro eclesiástico, atrás do substantivo que procura o adjetivo. Sílvio chama por Sílvia. Escutai; ao longe parece que suspira também alguma pessoa; é Sílvia que chama por Sílvio.

Ouvem-se agora e procuram-se. Caminho difícil e intrincado que é este de um cérebro tão cheio de coisas velhas e novas! Há aqui um burburinho de idéias, que mal deixa ouvir os chamados de ambos; não percamos de vista o ardente Sílvio, que lá vai, que desce e sobe, escorrega e salta; aqui, para não cair, agarra-se a umas raízes latinas, ali abordoa-se a um salmo, acolá monta num pentâmetro, e vai sempre andando, levado de uma força íntima, a que não pode resistir.

De quando em quando, aparecelhe alguma dama - adjetivo também - e oferece-lhe as suas graças antigas ou novas; mas, por Deus, não é a mesma, não é a única, a destinada $a b$ eterno para este consórcio. E Sílvio vai andando, à procura da única. Passai,
- Det medger jag.

Men stig för all del in i kanikens huvud ni också. Just nu suckas det på den här sidan. Vet ni vem det är som suckar? Det är substantivet från nyss, det som kaniken fäst på papperet när han hejdade pennan. Det kallar på ett visst adjektiv som inte infinner sig: "Kom med mig från Libanon, kom..." Och så talar det därför att huvudet är en prästs; hade det tillhört en modern människa så skulle språket ha varit Romeos: "Julia är solen ... gå upp, du sköna sol." Men i en ecklesiastisk hjärna är språket från Skriften. Vad betyder formlerna när allt kommer omkring? Kärlekspar från Verona eller Judéen, de talar alla samma idiom, det är som med dalern och dollarn, florinen och pundet som är samma pengar alltihop.

Låt oss alltså följa substantivet som kallar på sitt adjektiv genom vindlingarna $\mathrm{i}$ den ecklesiastiska hjärnan. Silvio ropar på Silvia. Lyssna: långt borta tycks även någon annan sucka; det är Silvia som kallar på Silvio.

$\mathrm{Nu}$ hör de varandra och söker mötas. Vad svår och krånglig vägen är genom en hjärna så full av gamla ting och nya! Här hörs ett sorl av idéer som nästan överröstar ropen från de båda; vi får inte förlora den eldige Silvio ur sikte där han går, kliver ner och klättrar upp, halkar och hoppar; här klänger han sig fast vid några latinska rötter för att inte falla, där bordar han en psalm och där bestiger han en pentameter, ständigt på väg framåt, driven av en inre kraft han inte kan motstå.

Då och då dyker någon dam upp adjektiv även hon - och bjuder honom sin gamla eller nya gunst, men vid Gud, hon är inte densamma, inte den enda, inte den $a b$ eterno ödesbestämda för denna förening. Och Silvio fortsätter sitt sökande efter den enda. 
olhos de toda cor, forma de toda casta, cabelos cortados à cabeça do Sol ou da Noite; morrei sem eco, meigas cantilenas suspiradas no eterno violino; Sílvio não pede um amor qualquer, adventício ou anônimo; pede um certo amor nomeado e predestinado.

Agora não te assustes, leitor, não é nada; é o cônego que se levanta, vai à janela, e encosta-se a espairecer do esforço. Lá olha, lá esquece o sermão e o resto. O papagaio em cima do poleiro, ao pé da janela, repete-lhe as palavras do costume e, no terreiro, o pavão enfuna-se todo ao sol da manhã; o próprio sol, reconhecendo o cônego, manda-lhe um dos seus fiéis raios, a cumprimentá-lo. E o raio vem, e pára diante da janela: "Cônego ilustre, aqui venho trazer os recados do sol, meu senhor e pai.” Toda a natureza parece assim bater palmas ao regresso daquele galé do espírito. Ele próprio alegra-se, entorna os olhos por esse ar puro, deixa-os ir fartarem-se de verdura e fresquidão, ao som de um passarinho e de um piano; depois fala ao papagaio, chama o jardineiro, assoa-se, esfrega as mãos, encosta-se. Não lhe lembra mais nem Sílvio nem Sílvia.

Mas Sílvio e Sílvia é que se lembram de si. Enquanto o cônego cuida em coisas estranhas, eles prosseguem em busca um do outro, sem que ele saiba nem suspeite nada. Agora, porém, o caminho é escuro. Passamos da consciência para a inconsciência, onde se faz a elaboração confusa das idéias, onde as reminiscências dormem ou cochilam. Aqui pulula a vida sem formas, os germens, e os detritos, os rudimentos e os sedimentos; é o desvão imenso do espírito. Aqui caíram eles, à procura
Vik undan, ögon av alla färger, former av alla slag, hår klippt efter solens huvud eller nattens; dö ut utan ekon, ljuva visor viskade på evig violin; Silvio begär ingen främmande, anonym kärlek vilken som helst, han begär en viss, utvald och ödesbestämd kärlek.

Bli inte rädd nu, kära läsare, det är inget; det är kaniken som reser sig och går fram till fönstret, stöder sig mot fönsterbrädan och tar en vilopaus från mödorna. Där står han och blickar ut, där glömmer han predikan och resten. På sin pinne bredvid fönstret upprepar papegojan sina vanliga fraser, och på gården stoltserar påfågeln i morgonsolen; solen själv känner igen kaniken och skickar en av sina trogna solstrålar med en hälsning. Och solstrålen kommer och stannar framför fönstret: "Illustre kanik! Här kommer jag med en hälsning från solen, min herre och far." Så tycks hela naturen klappa händer åt hans återkomst från sin andens galär. Själv gläder han sig, låter blicken vandra genom den klara luften och ögonen mätta sig med grönska och svalka till ljuden av en fågel och ett piano; sedan pratar han med papegojan, kallar på trädgårdsmästaren, snyter sig, gnuggar händerna, stöder sig mot fönsterbrädan. Han minns varken Silvio eller Silvia längre.

Men Silvio och Silvia har inte glömt varandra. Medan kaniken sysslar med annat fortsätter de att söka varandra utan att han vet eller ens anar det. $\mathrm{Nu}$ är det emellertid mörkt på vägen. Vi har gått från det medvetna till det omedvetna, där idéernas förvirrade utveckling sker, där hågkomsterna slumrar eller viskar. Här myllrar det av liv utan former, groddar och lämningar, rudiment och sediment; detta är andens väldiga källarrum. Här har de hamnat i sökandet efter varandra, ropande och suckande. 
um do outro, chamando e suspirando. Dê-me a leitora a mão, agarre-se o leitor a mim, e escorreguemos também.

Vasto mundo incógnito. Sílvio e Sílvia rompem por entre embriões e ruínas. Grupos de idéias, deduzindo-se à maneira de silogismos, perdem-se no tumulto de reminiscências da infância e do seminário. Outras idéias, grávidas de idéias, arrastam-se pesadamente, amparadas por outras idéias virgens. Coisas e homens amalgamam-se; Platão traz os óculos de um escrivão da câmara eclesiástica; mandarins de todas as classes distribuem moedas etruscas e chilenas, livros ingleses e rosas pálidas; tão pálidas, que não parecem as mesmas que a mãe do cônego plantou quando ele era criança. Memórias pias e familiares cruzam-se e confundem-se. Cá estão as vozes remotas da primeira missa; cá estão as cantigas da roça que ele ouvia cantar às pretas, em casa; farrapos de sensações esvaídas, aqui um medo, ali um gosto, acolá um fastio de coisas que vieram cada uma por sua vez, e que ora jazem na grande unidade impalpável e obscura. minha...

- Vem do Líbano, esposa

— Eu vos conjuro, filhas de Jerusalém...

Ouvem-se cada vez mais perto. Eis aí chegam eles às profundas camadas de teologia, de filosofia, de liturgia, de geografia e de história, lições antigas, noções modernas, tudo à mistura, dogma e sintaxe. Aqui passou a mão panteísta de Spinoza, às escondidas; ali ficou a unhada do Doutor Angélico; mas nada disso é Sílvio nem Sílvia. E eles vão rasgando, levados de uma força íntima, afinidade secreta, através de todos os obstáculos e por cima de todos os abismos. Também os desgostos hão de vir. Pesares sombrios, que não ficaram no
Läsarinna, tag min hand, läsare, håll i mig, så glider vi också ner.

Vida okända värld. Silvio och Silvia banar sig fram mellan embryon och ruiner. Grupper av idéer som logiskt slutleder sig går förlorade i tumultet av minnesbilder från barndomen och seminariet. Andra idéer, gravida med idéer, hasar tungt fram stödda på andra, jungfruliga idéer. Ting och människor gjuts samman; Platon bär glasögon som tillhör en skrivare i kyrkorådet; mandariner av alla de slag delar ut etruskiska och chilenska mynt, engelska böcker och bleka rosor; så bleka att de inte verkar vara samma rosor som kanikens mor planterade när han var barn. Fromma minnen korsas och förblandas med familjära. Här är de avlägsna rösterna från den första mässan, här är sångerna han hörde de svarta kvinnorna sjunga hemma på gården; trasor av känslor som förflyktigats, en fruktan här, en böjelse där, där borta en massa tråkigheter som kom var och en för sig och nu vilar där som en stor, mörk och ogripbar enhet.

- Kom med mig från Libanon, min brud ...

- Jag besvär eder, Jerusalems döttrar ...

Allt närmare hör de varandra. Nu når de fram till teologins, filosofins, liturgins, geografins och historiens djupare skikt, urgamla lärdomar, moderna begrepp, allt i en blandning, dogm och syntax. Här har Spinozas panteistiska hand passerat i smyg; där har doktor Angélico ristat ett märke med nageln, men inget av detta är Silvio eller Silvia. Och de fortsätter att bana sig fram drivna av en inre kraft, en hemlig samhörighet, genom alla hinder och över alla avgrunder. Även sorgerna måste de möta. Dystra bedrövelser som inte blev kvar i 
coração do cônego, cá estão, à laia de manchas morais, e ao pé deles o reflexo amarelo ou roxo, ou o que quer que seja da dor alheia e universal. Tudo isso vão eles cortando, com a rapidez do amor e do desejo.

Cambaleias, leitor? Não é o mundo que desaba; é o cônego que se sentou agora mesmo. Espaireceu à vontade, tornou à mesa do trabalho, e relê o que escreveu, para continuar; pega da pena, molha-a, desce-a ao papel, a ver que adjetivo há de anexar ao substantivo.

Justamente agora é que os dois cobiçosos estão mais perto um do outro. As vozes crescem, o entusiasmo cresce, todo o Cântico passa pelos lábios deles, tocados de febre. Frases alegres, anedotas de sacristia, caricaturas, facécias, disparates, aspectos estúrdios, nada os retém, menos ainda os faz sorrir. Vão, vão, o espaço estreita-se. Ficai aí, perfis meio apagados de paspalhões que fizeram rir ao cônego, e que ele inteiramente esqueceu; ficai, rugas extintas, velhas charadas, regras de voltarete, e vós também, células de idéias novas, debuxos de concepções, pó que tens de ser pirâmide, ficai, abalroai, esperai, desesperai, que eles não têm nada convosco. Amam-se e procuram-se.

Procuram-se e acham-se. Enfim, Sílvio achou Sílvia. Viram-se, caíram nos braços um do outro, ofegantes de canseira, mas remidos com a paga. Unem-se, entrelaçam os braços, e regressam palpitando da inconsciência para a consciência. "Quem é esta que sobe do deserto, firmada sobre o seu amado?”, pergunta Sílvio, como no Cântico; e ela, com a mesma lábia erudita, responde-lhe que "é o selo do seu coração", e que "o amor é tão kanikens hjärta finns här, liksom moraliska fläckar, och bredvid dem blänker den främmande, universella smärtans reflexer gula eller lila eller vad de nu kan ha för färg. Genom allt detta tränger de fram med kärlekens och åtråns hastighet.

Gungar det, läsare? Det är inte världen som störtar samman, det var kaniken som just satte sig. Han har fått sitt lystmäte av förströelser och återvänt till arbetsbordet. Nu läser han igenom vad han skrivit innan han fortsätter, han fattar pennan, väter den och sänker den mot papperet för att se vilket adjektiv han måste foga till substantivet.

Just nu börjar de två trängtande komma helt nära varandra. Rösterna höjs, entusiasmen stiger, hela Höga visan strömmar från deras feberheta läppar. Lustigheter, anekdoter från sakrististian, karikatyrer, vitsar, befängdheter, muntra upptåg, inget håller dem tillbaka eller får dem ens att le. De går och går, utrymmet blir trängre. Stanna där, halvt utsuddade profiler av dummerjönsar som fått kaniken att skratta och som han fullständigt har glömt; stanna där, utslätade veck, gamla charader, spelregler för voltarete, och ni också, celler till nya idéer, utkast till begrepp, $\mathrm{du}$ stoft som prompt skall vara pyramid, stanna där, knuffas, hoppas, förtvivla, ty ni har ingenting med dem att göra. De älskar och söker varandra.

De söker och finner varandra. Äntligen har Silvio funnit Silvia. De har funnit varandra och kastat sig i varandras famn, flämtande av utmattning, men gottgjorda av belöningen. De förenas, lägger armen om varandra och återvänder med bultande hjärtan från det omedvetna mot medvetenheten.

"Vem är hon som kommer hitupp från öknen, stödd på sin vän?” frågar Silvio som i Höga visan, och hon 
valente como a própria morte”.

Nisto, o cônego estremece. O rosto ilumina-se-lhe. A pena, cheia de comoção e respeito, completa o substantivo com o adjetivo. Sílvia caminhará agora ao pé de Sílvio, no sermão que o cônego vai pregar um dia destes, e irão juntinhos ao prelo, se ele coligir os seus escritos, o que não se sabe. svarar med samma lärda talförhet att hon är "en signetring vid ditt hjärta”, och att "kärleken är stark såsom döden”.

I samma ögonblick rycker kaniken till. Ansiktet lyser upp. Pennan kompletterar fylld av rörelse och respekt substantivet med adjektivet. Nu kommer Silvia att gå vid Silvios sida i den predikan som kaniken ska hålla endera dagen, och tillsammans skall de gå till trycket om han skulle kompilera och ge ut sina skrifter, vilket inte är känt.

Lalvez deva começar com uma breve apresentação. Meu nome é Hans
Berggren, sou natural da Suécia, moro em Florianópolis e traduzo
literatura, geralmente romances, de inglês ou português para o sueco. Sou autodidata; nunca planejei ou sonhei em ser tradutor, embora tenha sido leitor assíduo e onívoro desde menino. Foi meu amigo Einar Heckscher, poeta e cantor da nossa banda de rock progressivo da época, que me colocou neste caminho. Ele traduzira umas obras de William Burroughs e Charles Bukowski, e de repente estava com trabalho demais e sugeriu que a editora Norstedts me passasse a tradução de "Firewater Pond" de Michael Kimball, uma novela picaresca americana que não fez grande sucesso mas que ficou bem bem divertida também na tradução, sendo que em seguida ganhei cada vez mais e melhores livros a traduzir. John Updike, Don DeLillo, Richard Ford, Roddy Doyle, José Saramago e Salman Rushdie são alguns dos autores com quem tive o privilégio de trabalhar, além dos brasileiros, Chico Buarque e Patrícia Mello, traduzidos por iniciativa própria e publicados. De 1986 até agora, foram editados na Suécia cerca de 80 livros da minha tradução, divididos entre romances, contos, biografias e autobiografias. Parece muito, mas explica-se pelo fato que durante uns quinze anos eu traduzi quatro ou cinco romances por ano. Era um "galé do espírito", mesmo, trabalhava quinze horas por dia muitas vezes, mas consegui cumprir as "deadlines”, que é outra coisa que as editoras apreciam muito no tradutor.

Quando fui convidado a participar deste projeto, fiquei feliz pela honra e pela oportunidade de tentar traduzir um conto de um dos grandes escritores da literatura mundial.

Meu objetivo foi o de sempre: tentar interpretar da forma mais fiel e completa o texto original, e ao mesmo tempo evitar a tradução literal em lugares onde resultaria em "lusitanismos" alheios à lingua sueca. Na medida do possível, a tradução deve dar a impressão de um conto original, escrito na língua do leitor. No caso de nosso conto, também deve ter um leve toque de ter sido escrito há bastante tempo. Não mudarei a ortografia para aquela vigente na Suécia nos tempos de Strindberg, Machado e Eça de Queirós, mas algumas expressões que hoje não são muito frequentes podem constar na tradução. 
O trabalho foi um desafio e um prazer, e pensei que a parte mais difícil seria justamente estes comentários: não sou crítico literário, e escrever no mínimo 2000 palavras sobre as 1910 existentes na minha tradução não é meu modo normal de trabalhar; as minhas dúvidas e anotações à margem costumam ser mais curtas e esparsas, porém vi logo que havia pontos discutíveis em número suficiente para cumprir a tarefa. O que me levou de volta ao meu texto, e que me levou a novas dúvidas. Isto normalmente acontece na fase de corrigir o texto junto com um redator, o que costuma demorar um pouco, assim que o tempo possa dar a distância necessária para uma leitura mais "objetiva”, espera-se. Pois a tradução não é uma ciência exata, mas sim uma interpretação semelhante à de uma música. Varia com o intérprete, o que é saudável até um certo limite, e nunca estará perfeita, embora seja esta a busca. Aliás, a própria ciência nos seus momentos mais lúcidos admite que ainda estamos longe da última palavra sobre qualquer assunto, o que me dá uma certa esperança.

Pedi ao meu mestre de português da universidade de Estocolmo, Alexandre Fernandes Pastor, algumas observações sobre o conto e minha tradução, e ele apontou o seguinte:

"É evidente que Machado de Assis - pessimista que foi toda a vida - estava além de bom humor, também muito inspirado. Daí um texto que - embora válido e compreensível - excede nas inúmeras 'vassouradas' que ele nos dá: no fundo critica tudo e todos os aspetos existenciais possíveis. E fá-lo umas vezes com ironia cáustica, outras com humor. Começa de forma bem impressionista, com o Corcovado! Para logo nos avisar da sua capacidade e fraqueza para a psicologia, a sua memória nada esquece, sendo neste aspeto um escritor bem pré-proustiano. Já tinha ideias sobre as zonas do nosso cérebro (!), o que contem o lado esquerdo e o que há no direito, etc. De quando em quando avisa o leitor! Usa de uma simbologia engraçada e popular - o papagaio (que muita gente o é na vida), - e o pavão ( que ainda mais gente mostra ser quanto à sua própria pessoa). Não se esquece nem da Bíblia nem da Natureza, a passagem em que fala dos raios de sol é um exemplo. O 'sexo' das palavras, os grande amores tipo Tristão e Isolda, Romeu e Julieta, escolhendo nomes fáceis e populares como Silvia e Silvio! Enfim, quis ir bem ao fundo da grande 'paródia' que é a nossa vida. Na obra Memórias póstumas de Brás Cubas o autor contenta-se em não ter deixado filhos neste vale de lágrimas. Mas o conto peca, quanto a mim, por uma ambição excessiva de se referir a quase tudo. Neste sentido prefiro o género de $O$ Almocreve, o Homem no seu egoísmo máximo. Ocorreu-me ainda o caso de Mozart quando pela primeira vez tocou para o arquiduque Joseph II. Quando terminou quis saber a opinião do arquiduque. Este voltou-se para o inimigo de Mozart - Salieri - e este aconselhou o arquiduque dizendo: 'Diga-lhe que tem notas demasiadas'!"

Mas vamos ao conto.

Já nas primeiras linhas do conto surge um problema comum: Machado cita a Bíblia católica em português, eu sigo seu exemplo e cito a Bíblia na edição da igreja sueca (luterana) de 1917. O problema é que há diferenças, menores e maiores.

"Vem do Líbano, esposa minha, vem do Líbano, vem ... As mandrágoras deram o seu cheiro. Temos às nossas portas toda casta de pombos..."

fica na versão oficial sueca, traduzida palavra por palavra em português:

"Vem comigo do Líbano, minha noiva, vem comigo do Líbano... As maçãs de amor já estão a dar seu cheiro, e às nossas portas tem toda sorte de frutos preciosos...” 
E em seguida, ”Eu vos conjuro, filhas de Jerusalém, que se encontrardes o meu amado, lhe façais saber que estou enferma de amor..." fica

"Eu vos conjuro, filhas de Jerusalém, que se encontrardes o meu amado, lhe digais - sim, o que vades lhe dizer? Que estou enferma de amor!"

Obviamente a "licença poética” na tradução tem raízes profundas na história.

Já vamos aproveitar um pouco desta licença, o que às vezes me parece necessário para fazer uma tradução que funcione no idioma. Triste aquela tradução em que enxerga-se a língua original atrás das frases. Que a fidelidade perdoe o desejo de ser legível.

- ... 2222: suponho que o autor referia ao ano 2222 e adicionei um ”no ano ", ”år”, para definir.

- Então esta página...

esta página = denna sida, mas "sida" também significa "lado", e não se faz um livro de uma página só. Mudei para "dessa rader" = "estas linhas". vara fullbordat.)

- ... e tudo estará acabado. ... > e tudo estará concluído (och allt kommer att

- Tem quarenta anos ... No sueco o tempo presente não combina com o passado na sentença que segue. Aqui mudei para imperfeito: Tinha quarenta anos ...

- ... livros e livros $>$ livros e mais livros

- ... instaram tanto, que aceitou. > instaram tanto, que finalmente aceitou.

- As tiras saem-lhe das mãos. Aqui substituí "As tiras saem-lhe das mãos" por ”As linhas escorrem da sua caneta” para não sair do idiomático.

- Algumas trazem poucas emendas ou nenhumas > Algumas linhas recebem emendas, mas são poucas.

- ... falsa com Judas e outros diamantes > falsa como Judas e outras joias bonitas ("sköna juveler”, que é a expressão correspondente em sueco).

- Escutai: ao longe parece que suspira também alguma pessoa. (Acho meio estranho ouvir alguem suspirar ao longe, mas ok.)

- Há aqui um burburinho de ideias > Ouve-se aqui um burburinho de ideias

- Passai, olhos de toda cor, forma de toda casta, cabelos cortados à cabeça do Sol ou da Noite; (O que são "cabelos cortados à cabeça do Sol ou da Noite”? Há hoje alguém que saiba o que Machado quis dizer com isso? Traduzi literalmente, sabendo que Machado estreou como poeta e tinha uma tendência a grandes abstrações .)

- adjetivo também - > - adjetivo ela também -

- ... morrei sem eco $>$ morrei sem ecos (alt. tona bort)

- ... a espairecer do esforço, traduzido literalmente, não seria muito idiomático. Ele toma uma pausa de descanso dos esforços.

- ... repete-lhe as palavras de costume e, no terreiro, o pavão enfuna-se todo ao sol da manhã $>$... repete suas frases de costume e, no terreiro o pavão exibese/orgulha-se ao sol da manhã

- ... daquele galé do espírito > do seu galé do espírito 
- ... entorna os olhos por esse ar puro, deixa-os fartarem-se > deixa o olhar passear por esse ar puro e os olhos fartarem-se

-... cuida em cousas estranhas $>$ cuida em outras coisas

- ... é o desvão imenso do espírito > é o porão imenso do espírito ("andens väldiga källarrum”, um lugar para coisas que não se usam mais.

- ...as cantigas da roça que ele ouvia cantar às pretas, em casa $>$ as cantigas de trabalho que ele ouvia cantar às pretas em casa, lá na roça/fazenda (as origens do cônego ficam mais claras para o leitor sueco assim)

- ... um fastio de cousas que vieram cada uma por sua vez, e que ora jazem na grande unidade, impalpável e obscura > uma multidão de coisas chatas que vieram cada uma por sua vez, e que agora jazem em uma grande unidade, impalpável e obscura.

- Também os desgostos hão de vir > Terão que enfrentar também os desgostos

... todo o Cântico passa pelos lábios deles, tocados de febre ("passerar deras feberheta läppar” simplesmente não funciona) > ouve-se dos lábios febrís deles utslätade veck

... rugas extintas (?) Pensei e cheguei a pregas alisados (como num pano),

... pó que tens de ser pirâmide > tu, pó que insistes em ser/tornar-te pirâmide

As pequenas mudanças que fiz podem parecer desnecessárias ou até uma falta de respeito pelo original, mas não são. Para ficar fiel ao espírito, conteudo e estilo do texto original como um todo, é preciso de vez em quando até inventar coisas que simplesmente não constam no original. Por exemplo: trabalhando com as obras de Saramago, que gostava muito de ditados, tradicionais e de sua própria invenção, uma ou outra vez tive que substituir alguma coisa que não fazia sentido nenhum na direta tradução por um ditado sueco que caberia bem naquela situação, mas que não tinha nada a ver com o sentido literal daquilo que Saramago escreveu. Inventei para falar a verdade, pois uma tradução mais fiel teria sido ilegível, e o objetivo é facilitar a compreensão, não colocar a obra num pedestal fora do alcance do leitor.

Todo escritor quer ser lido - e em todas as línguas se for possível - e todo tradutor quer contar a história assim como a ouviu e entendeu, só que não resiste às exigências da própria imaginação e do próprio raciocínio frente a pontos problemáticos como por exemplo as "mandrágoras" e as "maçãs de amor" do início do conto.

Pesquisei e descobri que esta diferença tem explicação. A igreja católica nomeou e definiu a planta própria, que tem efeitos alucinógenos e usava-se em vários ritos pagãos e de magia, enquanto os luteranos - talvez guiados pelo mesmo medo puritano de tudo que cheira de festa e devassidão que os fez abolir o carnaval evitaram essa conexão através de uma traduzão literal do nome da mandrágora em hebreu, "planta da vida", que na Suécia tornou-se as mais apetitosas "maçãs de amor". Na verdade, a mandrágora, "alruna” em sueco, e os seus usos eram bem conhecidos também no norte da Europa na época das grandes traduções da Bíblia para as línguas germánicas. Assim a ideologia também influencia a tradução. 
Não é fácil, nosso ofício. Somos mentirosos, queremos e tentamos falar a verdade, e nem sabemos exatamente o que ela é. Parece-me uma bela imagem da condição humana, aliás. Se nem tentássemos, seria pior.

Rio Vermelho, 16 de setembro de 2013

Hans Berggren

hans.berggren@gmail.com

Tradutor profissional

Fonte: “O Cônego ou Metafísica do Estilo”. In: ASSIS, Machado de. Obra Completa.

Rio de Janeiro : Nova Aguilar 1994. v. II. Disponível em: <http://www.dominiopublico.gov.br/download/texto/bv000272.pdf> 